\title{
"Essential" Hypernatremia Due to Ineffective Osmotic and Intact Volume Regulation of Vasopressin Secretion
}

\author{
Frederick R. DeRubertis, Michael F. Michelis, Nama Beck, \\ James B. Field, and Bernard B. Davis \\ From the Department of Medicine, University of Pittsburgh, \\ Pittsburgh, Pennsylvania 15213
}

A в S T R A C T A physiological explanation for sustained hyperosmolality was sought in a patient with histiocytosis. During 23 days of observation with only sodium intake regulated at $100 \mathrm{mEq}$ daily, elevation (mean 310 $\mathrm{mOsm} / \mathrm{kg}$ of water) and fluctuation (range 298-323) of the fasting plasma osmolality were recorded. The presence of endogenous vasopressin was indicated by the patient's ability to concentrate the urine to as high as $710 \mathrm{mOsm} / \mathrm{kg}$ of water with a creatinine clearance of $84 \mathrm{cc} / \mathrm{min}$, and by dilution of the urine in response to alcohol. The failure of increasing fluid intake to as high as 6.2 liters daily to lower the plasma osmolality indicated that deficient fluid intake was not solely responsible for the elevated plasma osmolality. Hypertonic saline infusion during water diuresis resulted in the excretion of an increased volume of dilute urine. The water diuresis continued despite a rise in plasma osmolality from 287 to 339 . An isotonic saline infusion initiated during hydropenia resulted in a water diuresis which continued despite a rise in the plasma osmolality from 303 to 320 . Stable water diuresis induced during recumbency by either oral ingestion of water or intravenous infusion of normal saline was terminated by orthostasis and resumed with the return to the recumbent position. Antecedent alcohol ingestion blocked the antidiuresis of orthostasis. The data are interpreted as indicating impairment of the osmoreceptor mechanism as the primary cause of the hyperosmolar syndrome. They also indicate that vasopressin secretion was regulated primarily by changes in effective blood volume. Chlorpropamide was found to be an effective treatment for the syndrome.

This appeared as a preliminary report in 1970 Clin. Res. 18: 554 .

Received for publication 17 June 1970.

\section{INTRODUCTION}

The association of hypernatremia and hyperosmolality with neurologic lesions is not unusual. Zierler, in reviewing this subject in 1958, concluded that this increased total solute concentration of the body fluids was usually the result of relatively deficient fluid intake in obtunded or comatose patients rather than a specific distortion of water regulating mechanisms (1). While this is true in most instances, a group of patients with neurologic lesions and sustained hyperosmolality has been described with more complex and specific disturbances in water metabolism (2-18). In such patients lesions involving the hypothalamic-neurohypophyseal area have frequently been documented $(2-7,10-12,14$, 17,18 ) or strongly suspected from associated clinical findings $(8,9,13,16)$. Abnormalities in water metabolism associated with such lesions appear to result from (a) impaired thirst $(2-7,19),(b)$ impaired antidiuretic hormone production (diabetes insipidus) (20), or (c) altered regulation of antidiuretic hormone $(\mathrm{ADH})$ secretion (21). Since the neuronal "centers" for thirst and ADH production and secretion lie in close proximity to each other in the anterior hypothalamus (22), these disturbances may occur either singly or in combination. Conscious patients with hypothalamic lesions and sustained hyperosmolality have been described in whom adipsia or hypodipsia appeared to be the sole or predominant abnormality $(2-7)$. In such patients, like those reviewed by Zierler (1), hyperosmolality was primarily the result of inadequate fluid intake and was corrected by fluid administration (2-6).

However, patients with hypothalamic lesions have been described in whom mechanisms in addition to defective thirst appeared to be operative in maintaining sustained hyperosmolality (8-18). These complex disorders have been referred to as "essential" hyper- 
TABLE I

$24 \mathrm{hr}$ Urinary Steroid Excretion in Control State and after Metapyrone and ACTH

\begin{tabular}{|c|c|c|c|}
\hline Date & Drug & $\begin{array}{c}11,17-\mathrm{OH} \\
\text { Steroids }\end{array}$ & $\begin{array}{c}17- \\
\text { Ketosteroids }\end{array}$ \\
\hline & & $m g / 24 h r$ & $m g / 24 h r$ \\
\hline $6 / 17-18$ & - & 2.2 & 5.3 \\
\hline $6 / 18-19$ & - & 1.7 & 2.0 \\
\hline $6 / 19-20$ & - & 1.0 & 3.2 \\
\hline $6 / 20-21$ & $\begin{array}{l}\text { Metapyrone, } 750 \mathrm{mg} \\
\text { orally each } 4 \text { th } \mathrm{hr} \text { for } \\
\text { six doses }\end{array}$ & 2.3 & 5.0 \\
\hline $6 / 21-22$ & & 0.9 & 3.0 \\
\hline $6 / 22-23$ & ACTH, $40 \mathrm{U}$ i.m. twice & 8.8 & 6.5 \\
\hline $6 / 23-24$ & daily for 3 days & 19.0 & 10.0 \\
\hline $6 / 24-25$ & & 25.0 & 11.0 \\
\hline
\end{tabular}

natremia. Certain common features characterize such patients. The sustained hypernatremia is usually unassociated with a significant deficit of extracellular fluid volume as reflected by an absence of oliguria, azotemia, or decreased urinary sodium content (23). The spontaneous fluid intake is generally low relative to the elevated plasma osmotic pressure,| indicating defective thirst. In addition, the release of antidiuretic hormone in response to osmotic stimuli appears impaired. However, endogenous antidiuretic hormone production is at least partially intact as implied by concentration of urine under certain circumstances. In a number of these patients (9-14) hyperosmolality was not completely corrected by acute or chronic fluid loading excluding inadequate fluid intake as the predominant factor in the disruption of osmotic homeostasis. It has been suggested $(10-14,24)$ that the sustained hyperosmolality in this group (8-18) is the result of an elevated osmotic threshold for release of antidiuretic hormone. With such a disturbance in the osmotic regulation of antidiuretic hormone secretion, urine would be concentrated and water conserved only at very high levels of plasma osmolality ( $\mathrm{P}_{\mathrm{osm}}$ ). Thus, a new steady state at a high plasma osmolality would be maintained by this proposed upward "resetting of the hypothalamic osmostat."

This paper reports a patient with sustained hyperosmolality and hypopituitarism whose disorder can be classified as "essential" hypernatremia. Biopsy of the lung established the diagnosis of histiocytosis. The effect of both osmotic and volume stimuli on dilution and concentration of the urine were evaluated. The studies indicate that antidiuretic hormone was not released by changes in osmolality but appeared to be controlled by alterations in effective blood volume. The relationship between this abnormality and the maintenance of her hyperosmolality is discussed.

\section{CASE REPORT}

D.F., a $23 \mathrm{yr}$ old white housewife, had been well until 18 months before admission when she noted amenorrhea and gradual loss of axillary hair over a 12 month period. The patient had delivered a normal full-term baby girl 20 months before admission. Pregnancy, delivery, and immediate postpartum period were uncomplicated. She nursed the infant successfully for the next 5 months. However, menses failed to recur after the delivery and pubic hair did not completely regrow after being shaved in preparation for delivery. In the 5 months before her hospitalization the patient experienced weakness, anorexia, lethargy, and intermittent low grade fever. There was no history of cough or dyspnea. She was admitted to Presbyterian-University Hospital on 6/19/69. On examination her vital signs were normal. Height was $5 \mathrm{ft} 5$ inches and weight was $58 \mathrm{~kg}$. The patient was lethargic but oriented. She did not appear dehydrated. Pubic and axillary hair were diminished. Visual field and funduscopic examinations were normal. The chest was clear; the remainder of the examination, including the neurological, was normal. The patient was ambulatory and capable of self care but was noted to sleep through much of the day. Laboratory data included a hemoglobin of $12.6 \mathrm{~g} / 100 \mathrm{ml}$; hematocrit of $38 \%$, white blood cells (WBC) of $5700 / \mathrm{mm}^{3}$ with $51 \%$ polymorphonuclear neutrophils (PMN), 39\% lymphocytes, $1 \%$ mononuclears, and $9 \%$ eosinophils. Urinalysis, electrocardiogram, fasting blood sugar, uric acid, serum transaminase, alkaline phosphatase, Bromsulphalein retention, serum protein electrophoresis, calcium, and phosphorus were normal. Blood urea nitrogen was $12 \mathrm{mg} / 100 \mathrm{ml}$ with serum creatinine of $0.9 \mathrm{mg} / 100 \mathrm{ml}$. Serum sodium was $157 \mathrm{mEq} /$ liter (range of 11 determinations, 148160 ), chloride $116 \mathrm{mEq} /$ liter, potassium $4.3 \mathrm{mEq} / \mathrm{liter}$, and bicarbonate 27 mmoles/liter. Serum osmolality measured on two occasions during this admission were 322

TABLE II

Growth Hormone Levels by Immunoassay after Insulin Hypoglycemia

\begin{tabular}{ccc}
\hline \multicolumn{3}{c}{ Insulin tolerance test $(0.1 \mathrm{U} / \mathrm{kg})$} \\
\hline Time after insulin & Blood sugar & Growth hormone \\
\hline min & $m g / 100 \mathrm{ml}$ & $\mathrm{m \mu g} / \mathrm{ml}$ \\
0 & 92 & 0.8 \\
30 & 50 & 2.2 \\
60 & 60 & 1.2 \\
90 & 78 & 1.2 \\
120 & 88 & 1.0
\end{tabular}


and $331 \mathrm{mOsm} / \mathrm{kg}$ of water. Highest urine osmolality observed was $539 \mathrm{mOsm} / \mathrm{kg}$ of water. Mean $24 \mathrm{hr}$ fluid intake was 2.4 liters/day with urine output of 2.1 liters/day during this admission. Urinary steroid values are shown in Table $I$ and growth hormone response to insulin hypoglycemia in Table II. Maximum plasma follicle stimulating hormone level observed after 5 days of chlomiphene stimulation, $200 \mathrm{mg} /$ day, was $1.3 \mathrm{IU} / \mathrm{ml}$ (normal 2-10). Murphy-Pattee was $0.7 \mu \mathrm{g} / 100 \mathrm{ml}$ and protein-bound iodine (PBI) $2.9 \mu \mathrm{g} / 100 \mathrm{ml}$. All of these results were compatible with a diagnosis of pituitary insufficiency. Lumbar puncture revealed normal pressure with 8 lymphocytes $/ \mathrm{mm}^{3}$; protein was $137 \mathrm{mg} /$ $100 \mathrm{ml}$. Cultures were sterile.

Bilateral diffuse interstitial pulmonary infiltrates with patchy honeycomb changes were seen on chest film. Skull films showed no enlargement of the sella turcica. Skeletal survey, intravenous pyelogram, and bilateral carotid angiograms were normal. Pneumoencephalogram demonstrated a mass in the region of the hypothalamus. Bone marrow aspirate and biopsy revealed increased eosinophils. Needle biopsy of the liver and scalene node biopsy were normal. A presumptive diagnosis of histiocytosis was made and therapy with $60 \mathrm{mg}$ of prednisone daily was begun. After $1 \mathrm{wk}$ on this dosage, the patient was discharged on the 27th hospital day. Desiccated thyroid extract $180 \mathrm{mg} /$ day and prednisone $30 \mathrm{mg} /$ day in divided doses were taken at home for the next 85 days.

She was readmitted on $9 / 30 / 69$ with acute thrombophlebitis of the left lower extremity. In the interim she had become increasingly lethargic, inactive, and had gained $22 \mathrm{~kg}$ in weight. Appetite had increased markedly and this persisted 4 months after pharmacologic doses of prednisone were stopped, suggesting it might be related to the hypothalamic lesion. On examination blood pressure was $110 / 70 \mathrm{~mm} \mathrm{Hg}$ with a pulse of 92 beats/ min. Again she did not appear dehydrated. The patient had Cushingoid facies and was markedly obese. Recent memory was impaired and there was intermittent disorientation to time and place. Examination was otherwise unchanged. Blood urea nitrogen was $17 \mathrm{mg} / 100 \mathrm{ml}$ with serum creatinine of $1.2 \mathrm{mg} / 100 \mathrm{ml}$. Serum sodium was $160 \mathrm{mEq} /$ liter, potassium was $3.5 \mathrm{mEq} /$ liter, plasma osmolality was $337 \mathrm{mOsm} / \mathrm{kg}$ of water with a simultaneous urine osmolality of 542. Repeat lumbar puncture revealed normal pressure but cell count had increased to $95 / \mathrm{mm}^{3}$ with $86 \%$ lymphocytes and the remainder PMN's; protein content had increased to $295 \mathrm{mg} / 100$ $\mathrm{ml}$. The patient was transferred to the Clinical Research Unit of the hospital on 10/6/69 for studies of her salt and water metabolism. On 1/24/70 she underwent open biopsy of the lingula of the left lung. Microscopic ex- amination of the biopsy was compatible with histiocytosis.

\section{METHODS}

During the period of study on the Clinical Research Unit she was maintained on $180 \mathrm{mg}$ of desiccated thyroid extract and $5 \mathrm{mg}$ of prednisone daily in divided doses. Activity was unrestricted. She was offered a diet containing $100 \mathrm{mEq}$ of sodium daily and fluids were allowed ad lib. Sodium intake was measured by estimating the content of the diet from tables and correcting for portions returned to the kitchen. Fluid intake and urine output were quantitated. The patient was weighed and a venous blood sample obtained each morning in the fasting state. During this period of spontaneous fluid intake, blood volume was estimated by the sum of plasma volume (albumin- ${ }^{131} \mathrm{I}$ space) and red cell volume ( $\mathrm{RBC}-{ }^{51} \mathrm{Cr}$ space). Inulin space was determined by calculating the volume distribution of $3.2 \mathrm{~g}$ of inulin given intravenously, with correction for urinary excretion. The patient's thirst perception was assessed daily by direct questioning.

The response to the ingestion of either $20 \mathrm{ml} / \mathrm{kg}$ of tap water or $60 \mathrm{ml}$ of $50 \%$ alcohol was determined as previously described (25). The effect of chronic oral water loading was assessed by increasing fluid intake to over 3 liters daily. The response to chronic intravenous fluid therapy was evaluated by supplementing the patient's spontaneous oral fluid intake with 2-4 liters of $5 \%$ glucose in water for 4 consecutive days.

Water deprivation. The patient was allowed her usual evening meal at 6:00 p.m. At 9:00 p.m. she was asked to empty her bladder. She was then weighed and begun on total fluid deprivation. The test was continued until 11:00 a.m. the following day. Urine and plasma samples, and body weight in $\mathrm{kg}$, were obtained at the times recorded in Table IV.

Hypertonic saline infusion. After oral water loading, $5 \%$ saline was infused at a rate of $0.1 \mathrm{ml} / \mathrm{kg}$ of body weight per min.

Isotonic salinc. After overnight dehydration, isotonic saline was infused at a rate of $5.0 \mathrm{ml} / \mathrm{min}$ for $5 \mathrm{hr}$.

Orthostasis. After overnight dehydration, a water diuresis was established by the ingestion of $1200 \mathrm{ml}$ of tap water and maintained by giving orally at the time of each voiding a volume of tap water equal to the amount of urine excreted. When the water diuresis was stabilized, she was tilted to $75^{\circ}$ for $90 \mathrm{~min}$ and then returned to the recumbent position. On another day the study was repeated except 60 $\mathrm{ml}$ of $50 \%$ alcohol was given orally $15 \mathrm{~min}$ before the tilt.

Normal saline, orthostasis, and alcohol. Normal saline infusion ( $5 \mathrm{ml} / \mathrm{min})$ was repeated. After stable water diuresis was established during recumbency, the patient was tilted to $75^{\circ}$ for $90 \mathrm{~min}$. When stable water diuresis resumed after return to recumbency, the patient was given $60 \mathrm{ml}$ of $50 \%$ alcohol orally. $15 \mathrm{~min}$ after alcohol ingestion tilt was repeated. During this study urine was collected from indwelling bladder catheter at 20 -min intervals.

The patient's ability to alter urinary sodium concentration and conserve sodium was evaluated by restricting her dietary sodium to $25 \mathrm{mEq} /$ day. Since chlorpropamide therapy had been used successfully in a patient similar to the present patient (12), a trial of chlorpropamide using $250 \mathrm{mg}$ orally per day was undertaken.

During all acute studies blood samples were collected at appropriate intervals and urine samples were quantitated and accurately timed. The patient remained recumbent ex- 
TABLE III

Summary of Observations on Spontaneous Fluid Intake and Chronic Oral and Intravenous Fluid Loading, $100 \mathrm{mEq}$ Sodium Diet

\begin{tabular}{|c|c|c|c|c|c|}
\hline & Intake & Urine volume & Posm & Uosm & $\frac{\text { Uosm }}{\text { Posm }}$ \\
\hline Spontane & did intake $\left(23^{n}\right.$ & observation) & mOsm & water & \\
\hline Mean & 2155 & 1868 & 310 & 352 & 1.1 \\
\hline SD & \pm 374 & \pm 433 & \pm 7.6 & \pm 66 & \\
\hline Range & $(1420-3127)$ & $(1497-2277)$ & $(298-323)$ & $(241-517)$ & \\
\hline \multicolumn{6}{|c|}{ Chronic oral water loading (7 days observation) } \\
\hline Mean & 3340 & 2794 & 309 & 246 & 0.8 \\
\hline SD & \pm 296 & \pm 609 & \pm 7.1 & \pm 75 & \\
\hline Range & $(3110-3780)$ & $(2387-3925)$ & $(303-317)$ & $(150-360)$ & \\
\hline \multicolumn{6}{|c|}{ Chronic i.v. fluid loading ( $5 \%$ glucose per water for 4 days) } \\
\hline Mean & 4760 & 3944 & 312 & 172 & 0.6 \\
\hline SD & \pm 1163 & \pm 984 & \pm 1 & \pm 34 & \\
\hline Range & $(3340-6190)$ & $(3184-5293)$ & $(311-314)$ & (129-209) & \\
\hline
\end{tabular}

cept during orthostasis or when she rose to void. Sodium and potassium were measured by flame photometry and osmolality by freezing point depression. Inulin was determined by the anthrone method (26), creatinine by the method of Bonsnes and Taussky (27), and aldosterone by the technique of Kliman and Peterson (28) as modified by Vagnucci (29).

\section{RESULTS}

Observations on spontaneous fluid intake. During a 23 day period of observation on spontaneous fluid intake and activity, the patient was ambulatory, communicative, and capable of ordinary self care. She was, however, lethargic and spent much of the day recumbent. Although she usually admitted that she was thirsty when directly asked, she seldom spontaneously complained of thirst. A relatively constant weight was maintained (mean $79.5 \mathrm{~kg} \pm 0.7 \mathrm{sD}$ ) during this period, implying net fluid balance. Mean creatinine clearance was $84 \mathrm{ml} /$ min. Multiple determinations of serum creatinine, blood urea nitrogen, potassium, and bicarbonate were normal. On a sodium intake which approximated $100 \mathrm{mEq}$ daily, mean daily urinary sodium excretion was $93 \mathrm{mEq}$, reflecting sodium balance as did the stable body weight. Inulin space was calculated as 11.2 liters with a predicted value of 12 liters using $16 \%$ of body weight on the day of the study (30). Blood volume was 3.3 liters with a standard value of 3.7 liters corrected to height and lean body weight.

Table III indicates the mean values, ranges, and standard deviations of the parameters monitored during this period. The mean plasma osmolality was high (310 $\mathrm{mOsm} / \mathrm{kg}$ of water with a normal value of $288 \pm 3 \mathrm{sD}$ for this laboratory). The fluctuations in the Posm are depicted in the scatter diagram (Fig. 1). Maximum urine osmolality (Uosm) observed on a spontaneously voided specimen in the absence of exogenous vasopressin was $710 \mathrm{mOsm} / \mathrm{kg}$ of water. Several urine specimens had osmolalities of 700 or above and individual specimens were obtained each day with osmolalities at least twice that of plasma. These concentrated specimens occurred at urine flow rates at high as $\mathrm{ml} / \mathrm{min}$. This and the mean creatinine clearance of $84 \mathrm{ml} / \mathrm{min}$ indicate that these concentrated urine specimens were related to the presence of antidiuretic hormone and not to a severe rduction in glomerular filtration rate (31). In addition, antidiuresis was inhibited and urinary dilution occurred in response to alcohol ingestion (Fig. 2), further confirmation of the presence of endogenous antidiuretic hormone secretion (32).

Although mean fluid intake $(2155 \mathrm{ml} /$ day $)$, urine volume (1868 ml/day), and osmolality (352 $\mathrm{mOsm} / \mathrm{kg}$ of water) were not abnormal in absolute terms during the period of spontaneous fluid intake, all were abnormal when considered relative to the patient's elevated Posm. Since elevated $\mathrm{Posm}_{\mathrm{m}}$ is normally a potent stimulus to drinking (33) and antidiuresis (34), a positive correlation would ordinarily be expected between Posm and urinary concentration and between $\mathrm{P}_{\mathrm{s} m}$ and fluid intake. In Fig. 1, Posm, measured each morning, is plotted against the fluid intake and the production of a concentrated urine (as reflected by a mean $\mathrm{U}_{\mathrm{osm}} / \mathrm{P}_{\mathrm{s} m \mathrm{~m}}$ ratio greater than one) for the $24 \mathrm{hr}$ period after the corresponding Posm. As is evident from the wide scatter, no correlation was found.

Maximum Uosm observed after injected vasopressin was $1480 \mathrm{mOsm} / \mathrm{kg}$ of water, reflecting unimpaired renal concentrating ability. In addition the patient was able to dilute her urine (minimum $U_{o s m}$ is $66 \mathrm{mOsm} / \mathrm{kg}$ of 
water) and widely vary urinary sodium concentration (1-206 $\mathrm{mEq} /$ liter) in response to varying sodium intakes. On a $25 \mathrm{mEq}$ sodium diet $24 \mathrm{hr}$ urinary aldosterone excretion was $15.3 \mu \mathrm{g}$ (normal 3-19 $\mu \mathrm{g}$ ). Sodium balance was maintained on this restricted intake over a period of several months.

Response to acute and chronic water loading. As can be seen from the data in Table III chronic water loading either orally or intravenously up to 6.2 liters/day failed to significantly lower mean $P_{0 s m}$ but resulted in increased volumes of dilute urine. Posm was $311 \mathrm{mOsm} /$ $\mathrm{kg}$ of water at the initiation and 312 at the termination of $5 \%$ dextrose and water administration (Fig. 3). The infusion increased mean daily fluid intake by an average of 2.6 liters over spontaneous intake. Blood sugars remained in the euglycemic range and urine reductions done four times daily were negative during the infusion. Mean daily Uosm fell from 210 to $129 \mathrm{mOsm} /$ $\mathrm{kg}$ water and urine volume rose progressively during the period of the infusion.

As can be seen in Fig. 3 urine remained dilute and Posm high in the $24 \mathrm{hr}$ after the cessation of intravenous infusion. During this period negative fluid balance developed with weight loss. Subsequently urinary concentration increased, Posm transiently fell, and weight increased. The response to chronic oral water loading was comparable. Posm was $308 \mathrm{mOsm} / \mathrm{kg}$ of water at the initiation of the study and 314 after 7 days of water loading during which an average of 1.1 liters daily above spontaneous intake was ingested. Mean urine osmolality again fell progressively from 360 to $150 \mathrm{mOsm} / \mathrm{kg}$ of water and urine volumes increased.

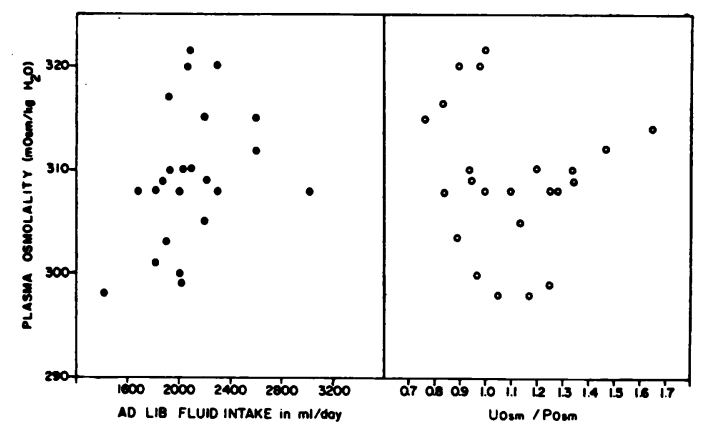

Figure 1 Correlation of plasma osmolality ( $\mathrm{P}_{\mathrm{osm}}$ ) with ad lib. fluid intake and with concentration of the urine. Scattergram depicts the wide range of values of the fasting $\mathrm{P}_{\mathrm{Osm}}$ during a 23 day period of spontaneous fluid intake. No correlation was found between the morning fasting $\mathrm{P}_{\mathrm{osm}}$ and the volume of fluid ingested in the succeeding $24 \mathrm{hr}$ period. Similarly there was no correlation between $\mathrm{P}_{\mathrm{Osm}}$ and concentration of the urine excreted in that period. Concentration of the urine is expressed as the mean urine osmolality $\left(\mathrm{U}_{\mathrm{osm}} / \mathrm{P}_{\mathrm{osm}}\right)$ with a value greater than one representing urinary concentration.

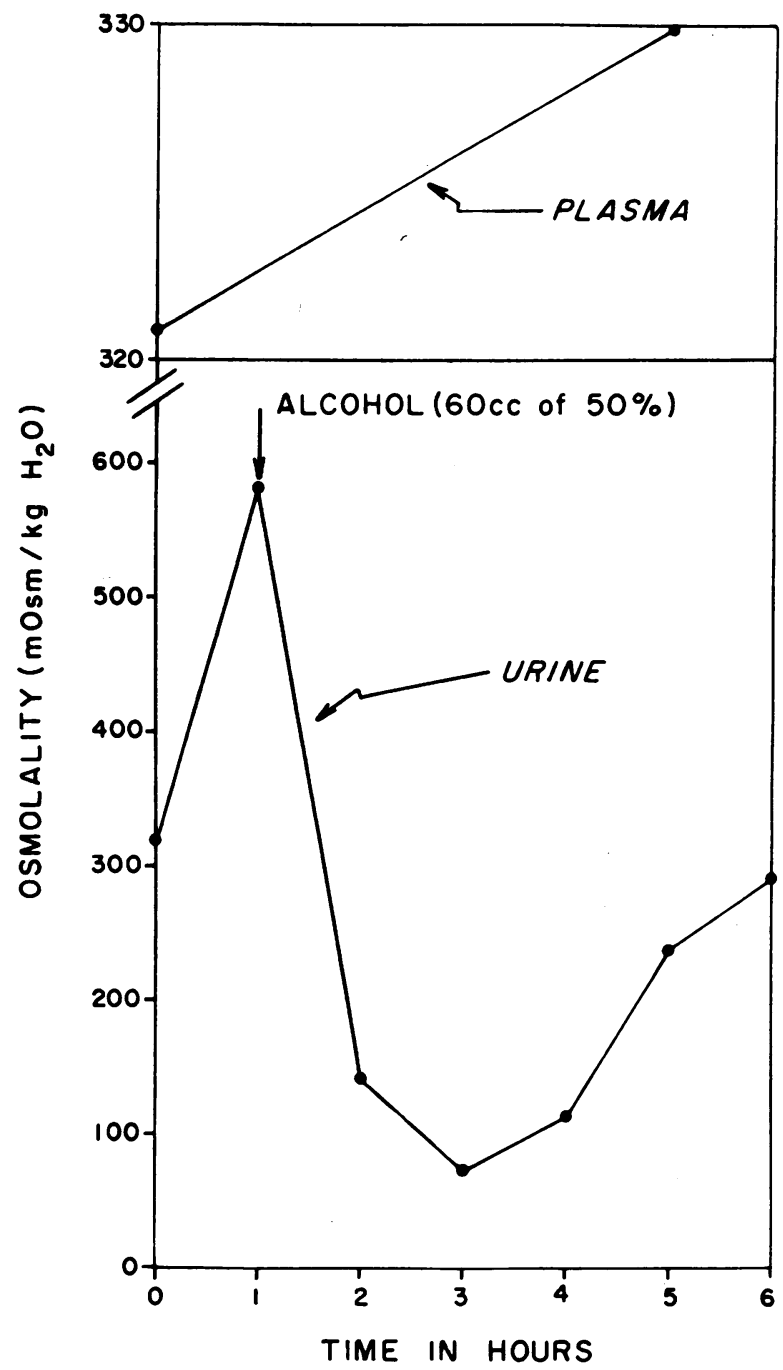

FigURE 2 Response to alcohol. After overnight dehydration, administration of ethyl alcohol resulted in prompt urinary dilution and water diuresis.

The response to an acute oral water load is shown in Fig. 4. Water diuresis occurred even though Posm remained high, the minimum $\mathrm{P}_{\mathrm{osm}}$ observed being 307 $\mathrm{mOsm} / \mathrm{kg}$ of water $1 \mathrm{hr}$ after water ingestion. This study was repeated and quite similar results were obtained.

Response to water deprivation. At the initiation of total fluid deprivation, the patient's plasma osmolality was 303 and she weighed $87.1 \mathrm{~kg}$ (Table IV). After $10 \mathrm{hr}$ the plasma osmolality had risen to 319 and the weight had decreased to $86 \mathrm{~kg}$. The urine osmolality was 411 . Over the next $4 \mathrm{hr}$ she lost another $0.3 \mathrm{~kg}$ body weight, the plasma osmolality rose to 326 , and the urine to 604 . The rate of urine flow over the last $4 \mathrm{hr}$ was stable at $0.2-0.3 \mathrm{ml} / \mathrm{min}$. 
Response to hypertonic saline. Hypertonic saline was given to evaluate the patient's ability to concentrate the urine in response to an acute rise in plasma osmolality. As shown in Fig. 5, Posm in response to hypertonic saline rose markedly $(52 \mathrm{mOsm} / \mathrm{kg}$ of water, $18 \%$ ) in 6 $\mathrm{hr}$ without a resultant antidiuresis. Urine flow, rather than decreasing, rose to a peak of $18.3 \mathrm{ml} / \mathrm{min} 90 \mathrm{~min}$ after cessation of infusion. This was accompanied by a peak osmolar clearance of $8.3 \mathrm{ml} / \mathrm{min}$ and a peak free water clearance $\left(\mathrm{C}_{\mathrm{H}_{2} \mathrm{O}}\right)$ of $10 \mathrm{ml} / \mathrm{min}$. As shown in Fig. 5, water diuresis was in progress $5 \mathrm{hr}$ after cessation of the infusion and $P_{0 s m}$ rose an additional 25 $\mathrm{mOsm} / \mathrm{kg}$ of water. Total cumulative urine volume excreted equalled volume of fluid administered by both water ingestion and saline infusion by the $7 \mathrm{th} \mathrm{hr}$ of the study. Approximately $25 \%$ of the administered sodium load was excreted within $4 \mathrm{hr}$ of completion of the infusion with a peak urinary sodium excretion of $950 \mu \mathrm{Eq} /$ min. Within $24 \mathrm{hr}$ sodium balance was restored. These values for sodium excretion are comparable to those found in normal subjects given $5 \%$ saline at similar rates $(35,36)$, making it unlikely that an abnormally delayed excretion of sodium contributed significantly to the marked rise in Posm. At a Posm of $339 \mathrm{mOsm} / \mathrm{kg}$ of water, the patient's sensorium was seriously clouded. Water diuresis was still in progress but at a decreased rate. Vasopressin infusion readily terminated the water diuresis and markedly improved her sensorium.

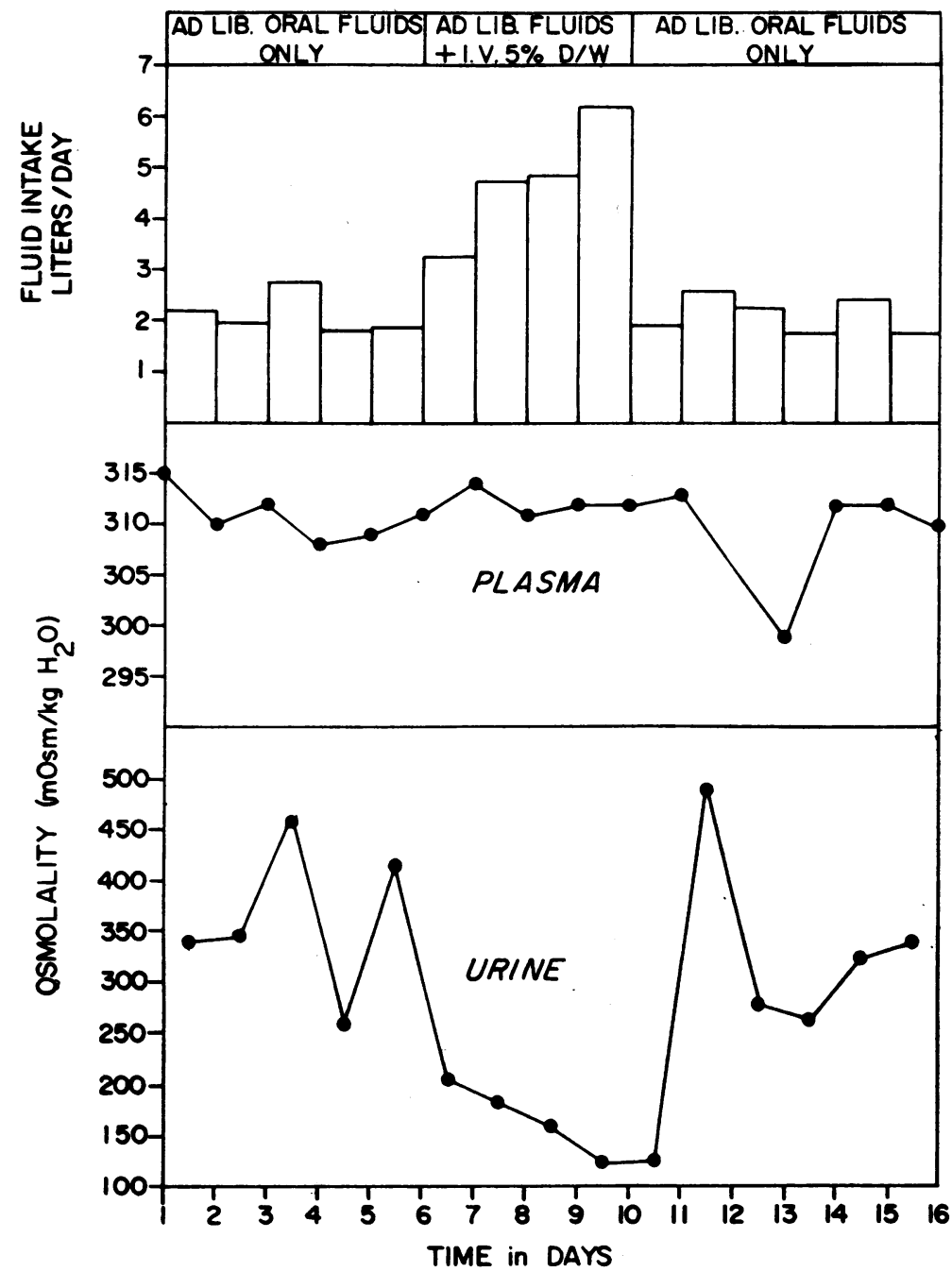

Figure 3 Response to intravenous fluid loading. Intravenous glucose/water (i.v. $5 \% \mathrm{D} / \mathrm{W}$ ) up to 4 liters daily (total fluid intake up to 6.2 liters daily) failed to lower plasma osmolality. Progressive urinary dilution occurred with plasma osmolality $\left(\mathrm{P}_{\mathrm{osm}}\right)$ still high during the period of infusion (mean Posm $312 \mathrm{mOsm} / \mathrm{kg}$ of water). 


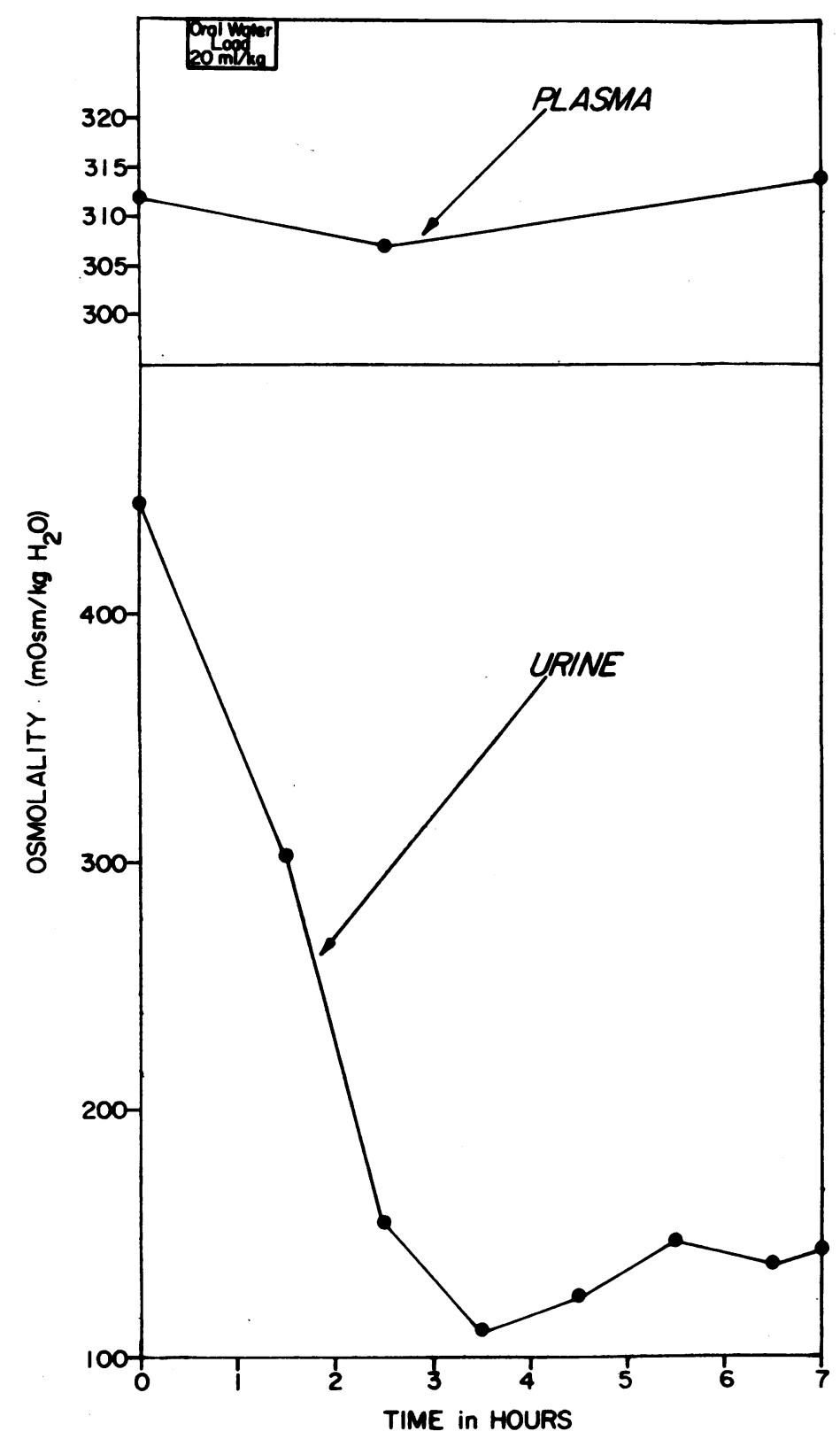

FIGURE 4 Response to acute oral water load. Administration of an oral water load (20 $\mathrm{ml}$ of tap water per $\mathrm{kg}$ of body weight) resulted in urinary dilution (minimum urine osmolality $108 \mathrm{mOsm} / \mathrm{kg}$ of water) and a water diuresis at an elevated plasma osmolality (minimum value $307 \mathrm{mOsm} / \mathrm{kg}$ of water).

Normal saline infusion. The response to isotonic saline infusion is shown in Fig. 6. As can be seen a sustained water diuresis was induced which resulted in a rise of Posm of $17 \mathrm{mOsm} / \mathrm{kg}$ of water (5.7\%) over a 7 hr period. Water diuresis began after approximately 500 $\mathrm{ml}$ of saline had been given. Total cumulative urine volume excreted from onset of the saline infusion equalled the volume of saline given by the 7 th $\mathrm{hr}$ of the study.
Peak urine flow was $5.1 \mathrm{ml} / \mathrm{min}$ and peak $\mathrm{C}_{\mathrm{H}_{2} \mathrm{O}}$ was $2.9 \mathrm{ml} / \mathrm{min}$. Exogenous vasopressin was given when Posm reached $320 \mathrm{mOsm} / \mathrm{kg}$ of water $90 \mathrm{~min}$ after cessation of the saline infusion. Water diuresis, still in progress at that time, was readily terminated.

Response to orthostasis. Fig. 7 depicts the patient's response to orthostasis. In normal subjects orthostasis is known to produce antidiuresis, which is probably de- 


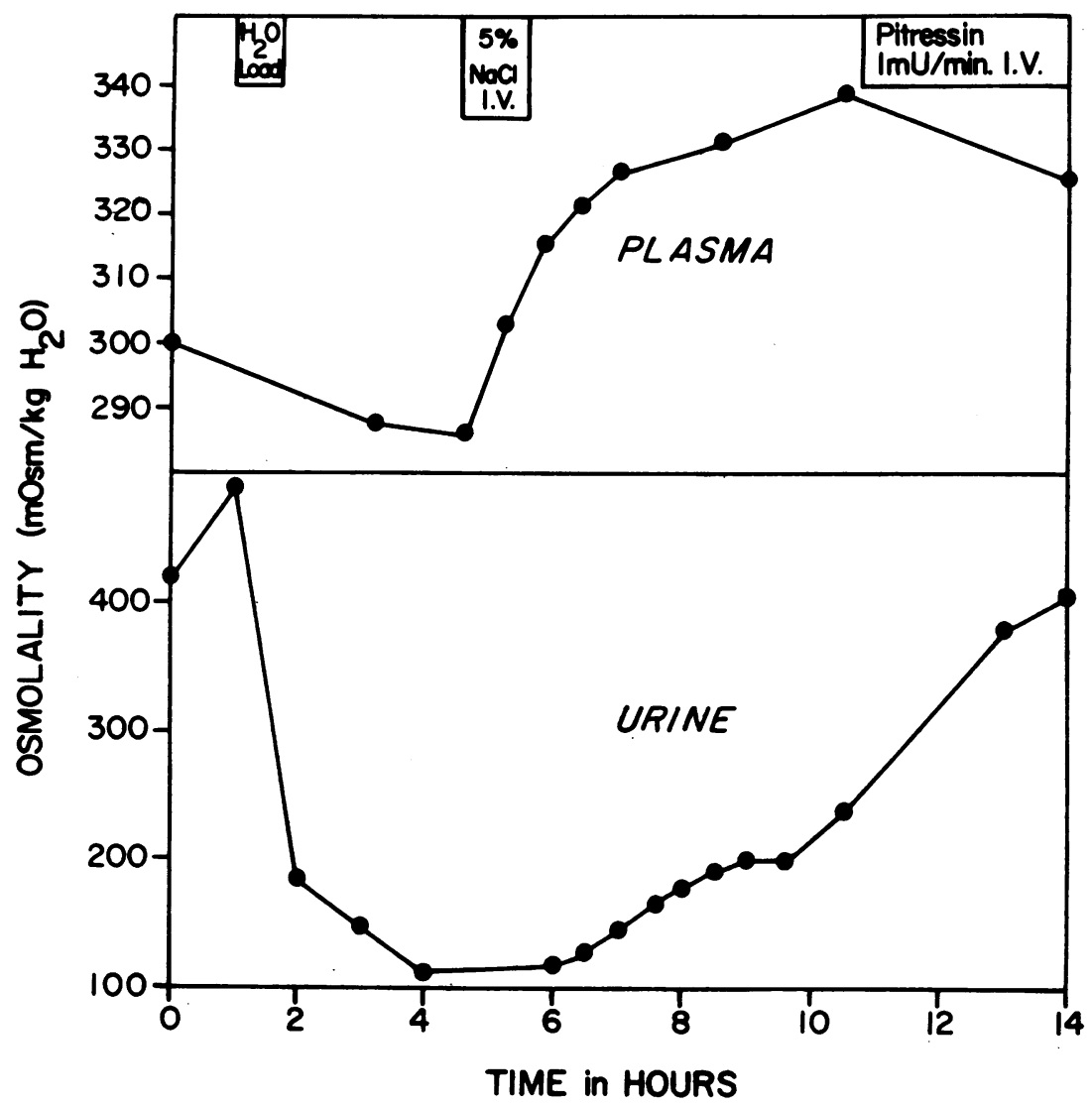

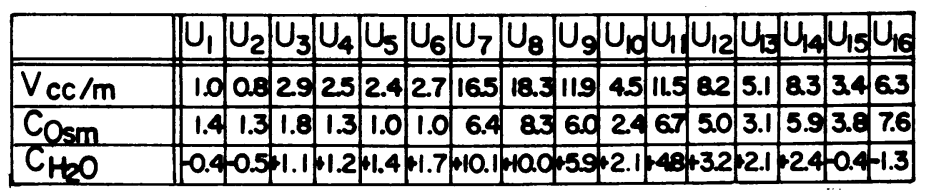

FIGURE 5 Response to hypertonic saline infusion. After establishment of a water diuresis with an oral water load $\left(\mathrm{H}_{2} \mathrm{O}\right.$ load), $20 \mathrm{ml} / \mathrm{kg}$ body weight, infusion of intravenous hypertonic saline $(5 \% \mathrm{NaCl}$ i.v.) $0.1 \mathrm{ml} / \mathrm{kg}$ of body weight per min, did not result in urinary concentration despite a marked acute rise in plasma osmolality ( $52 \mathrm{mOsm} / \mathrm{kg}$ of water, $18 \%$ in $6 \mathrm{hr}$ ). Rather, urine flow (maximum $18.3 \mathrm{ml} / \mathrm{min}$ ) increased with saline infusion. The maximum values were noted $90 \mathrm{~min}$ after cessation of the infusion. Water diuresis, still in progress at hr 10, was terminated with exogenous vasopressin (Pitressin, $1 \mathrm{mU} / \mathrm{min}$ i.v.). Table, at bottom, depicts $\mathrm{V}, \mathrm{C}_{\mathrm{osm}}$, and $\mathrm{C}_{\mathrm{H}_{2} \mathrm{O}}$ in milliliters per minute for individual determinations corresponding in sequence to points plotted for urine osmolality.

pendent on a reduction of effective circulating blood volume by pooling of blood in the legs rather than a reduction of total plasma volume, since iso-oncotic albumin infusion does not prevent the antidiuresis (37). Alcohol, which blocks the secretion of antidiuretic hormone, can prevent orthostatic antidiuresis $(32,38,39)$. As shown in Fig. 7, tilt to $75^{\circ}$ interrupted a stable water diuresis with the Uosm rising to $649 \mathrm{mOsm} / \mathrm{kg}$ of water. Water diuresis resumed when the patient was returned to the recumbent position. Posm remained stable during the study after a small initial fall which resulted from water loading. When the study was repeated (Fig. 7) giving $60 \mathrm{ml}$ of $50 \%$ alcohol orally before tilting, antidiuresis was not observed. Further evaluation of dilution and concentration of the urine in response to effective volume changes are summarized in Fig. 8. Volume expansion caused by infusion of approximately $400 \mathrm{ml}$ of saline initiated a water diuresis which was terminated by tilting her despite the continued infusion of saline. Recumbency was associated with restoration of the wa- 
TABLE IV

Effect of Dehydration on Body Weight and Urine and Plasma Osmolality

\begin{tabular}{rcccc}
\hline Time & Posm & Uosm & Weight & $\mathrm{V}$ \\
\hline 9:00 p.m. & 303 & & $\mathrm{~kg}$ & $\mathrm{ml} / \mathrm{min}$ \\
6:00 a.m. & & 249 & 86.0 & 1.6 \\
7:00 a.m. & 319 & 411 & & 0.7 \\
8:00 a.m. & & 463 & & 0.3 \\
9:00 a.m. & & 511 & & 0.3 \\
10:00 a.m. & 324 & 596 & & 0.2 \\
11:00 a.m. & 326 & 604 & 85.7 & 0.3 \\
\hline
\end{tabular}

$\mathrm{P}_{\text {osm }}=$ plasma osmolality $\left(\mathrm{mOsm} / \mathrm{kg}\right.$ of $\left.\mathrm{H}_{2} \mathrm{O}\right), \mathrm{U}_{\mathrm{osm}}=$ urine osmolality $\left(\mathrm{mOsm} / \mathrm{kg}\right.$ of $\left.\mathrm{H}_{2} \mathrm{O}\right)$, and $\mathrm{V}=$ urine flow rate.

ter diuresis. Antecedent alcohol administration again inhibited the antidiuresis of tilting.

Response to chlorpropamide. The response to chlorproplamide therapy, $250 \mathrm{mg}$ orally per day, is shown in Fig. 9. The effectiveness of this agent in diabetes in- sipidus has recently been reported (40-43). Mahoney and Goodman (12) employed chlorpropamide successfully in a similar patient with chronic hypernatremia. In the present patient, significant reduction of Posm was not observed until the 4th day of therapy with chlorpropamide and was sustained for 2 days after the drug was temporarily discontinued. At the time of this report the patient had received chlorpropamide therapy for a total of $6 \mathrm{wk}$. Posm has recently ranged from 282 to 296 $\mathrm{mOsm} / \mathrm{kg}$ of water, the most sustained reduction observed. Clinically, corection of the hyperosmolality was accompanied by a marked improvement in the patient's mental status.

\section{DISCUSSION}

This patient demonstrates the features of the syndrome which has been termed "essential hypernatremia" (8-18). Previous examples of essential hypernatremia have been postulated to be on the basis of an elevated osmotic threshold for vasopressin release $(10-15,24)$. The ob-

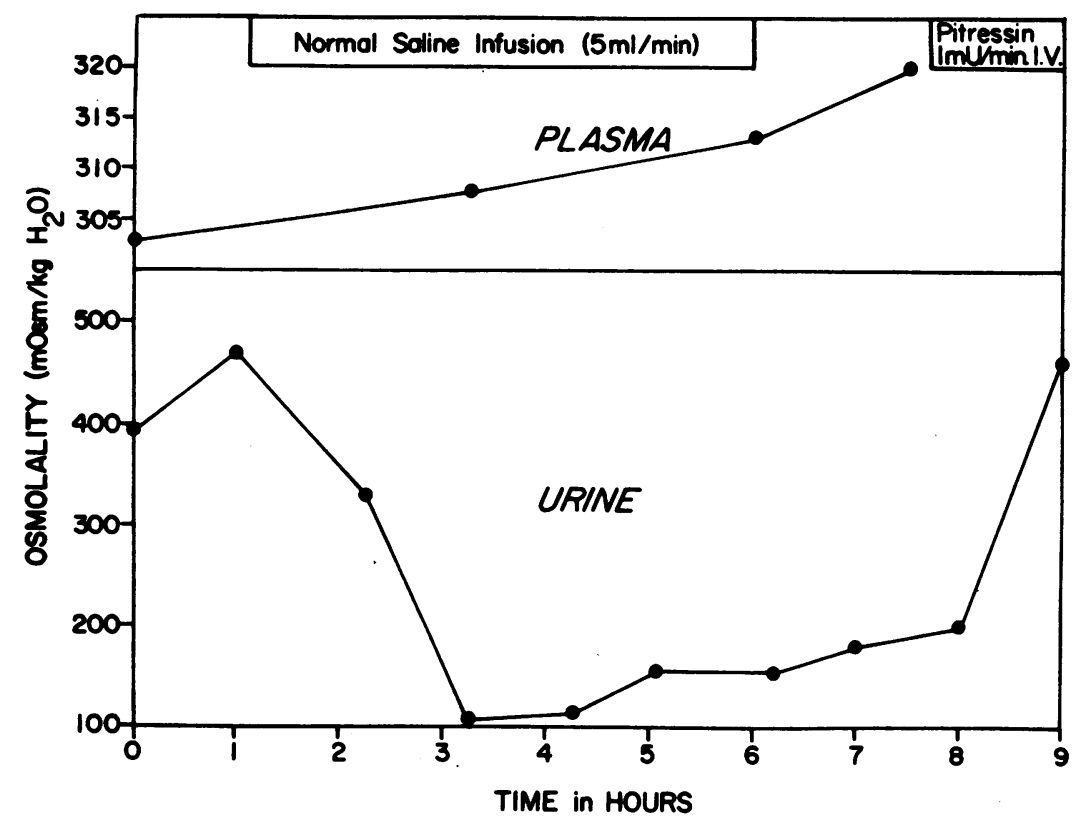

\begin{tabular}{|l||c|c|c|c|c|c|c|c|c|c|}
\hline & 1 & 2 & 3 & 4 & 5 & 6 & 7 & 8 & 9 & 10 \\
\hline$\nabla_{\mathrm{cc} / \mathrm{m}}$ & 1.1 & 0.8 & 1.2 & 4.0 & 4.5 & 2.8 & 3.5 & 5.0 & 4.2 & 0.8 \\
\hline $\mathrm{C}_{\mathrm{Omm}}$ & 1.4 & 1.2 & 1.3 & 1.3 & 1.6 & 1.4 & 1.7 & 28 & 2.6 & 20 \\
\hline $\mathrm{C}_{\mathrm{H} \mathrm{O}}$ & -0.3 & -0.4 & -0.1 & +2.7 & +29 & +1.4 & +1.8 & +2.2 & +1.6 & -1.2 \\
\hline
\end{tabular}

FIGURE 6 Response to normal saline infusion. After overnight dehydration, infusion of approximately $500 \mathrm{ml}$ of normal saline resulted in urinary dilution ( $\mathrm{U}_{\mathrm{osm}}$ is $102 \mathrm{mOsm} / \mathrm{kg}$ of water). With continued saline infusion, a sustained water diuresis was observed despite a rising plasma osmolality (301-320 $\mathrm{mOsm} / \mathrm{kg}$ of water). Water diuresis was terminated with exogenous vasopressin (Pitressin $1 \mathrm{mU} / \mathrm{min}$ i.v.). Table, at bottom, depicts V, Cosm, and $\mathrm{C}_{\mathrm{H}_{2} \mathrm{O}}$ in milliliters per minute for individual determinations corresponding in sequence to points plotted for urine osmolality. 


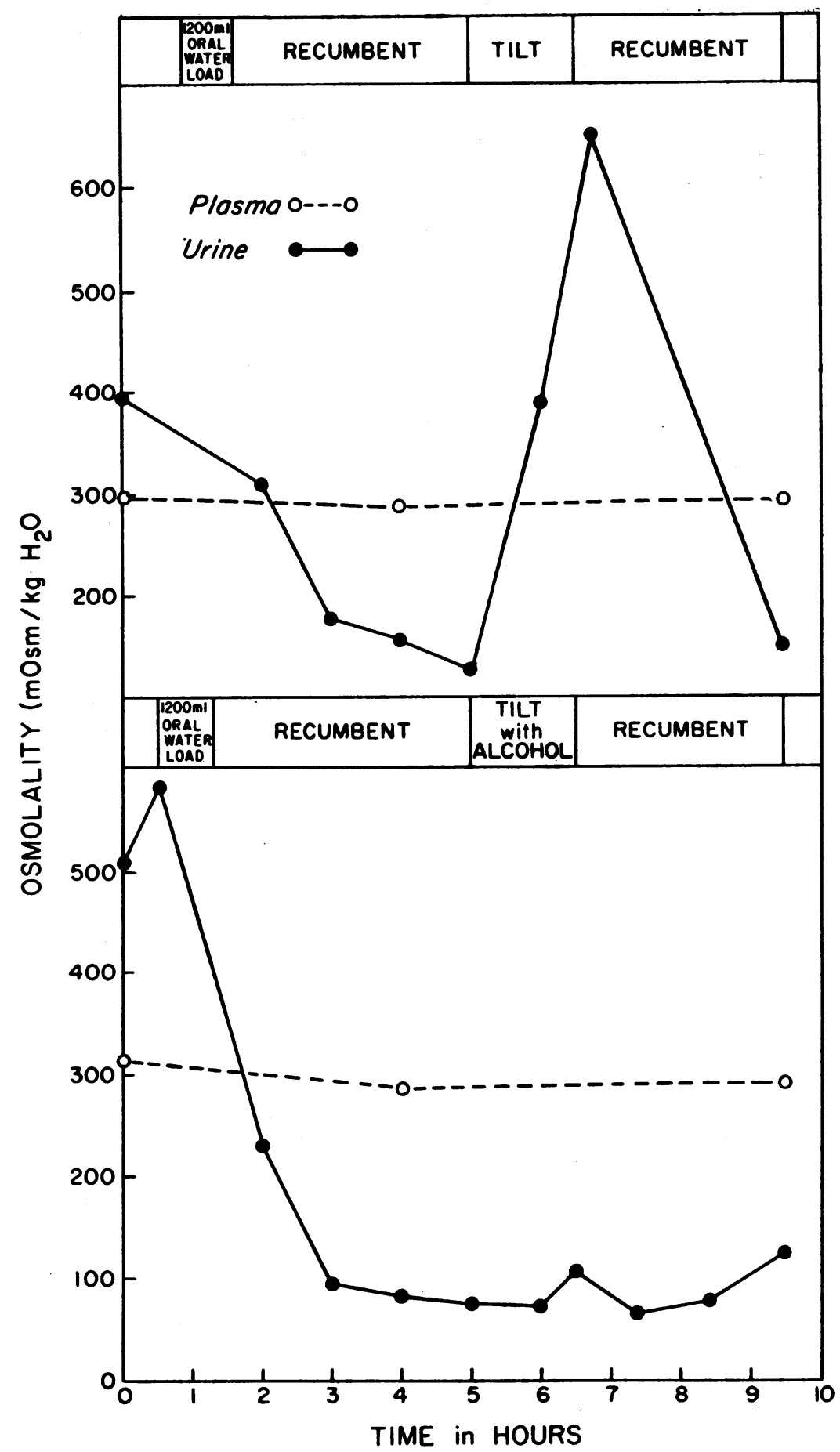

FIgURE 7 Response to orthostasis. Upper panel. After establishment of a water diuresis with an oral water load during recumbency, tilting to $75^{\circ} \mathrm{C}$ for $90 \mathrm{~min}$ resulted in urinary concentration with urine osmolality rising from 129 to 649 $\mathrm{mOsm} / \mathrm{kg}$ of water. Water diuresis resumed with recumbency. Lower panel. Ingestion of ethyl alcohol $15 \mathrm{~min}$ before tilting blocked the antidiuretic response. During both studies water was given orally at the time of each voiding in a volume equal to the volume of urine. 


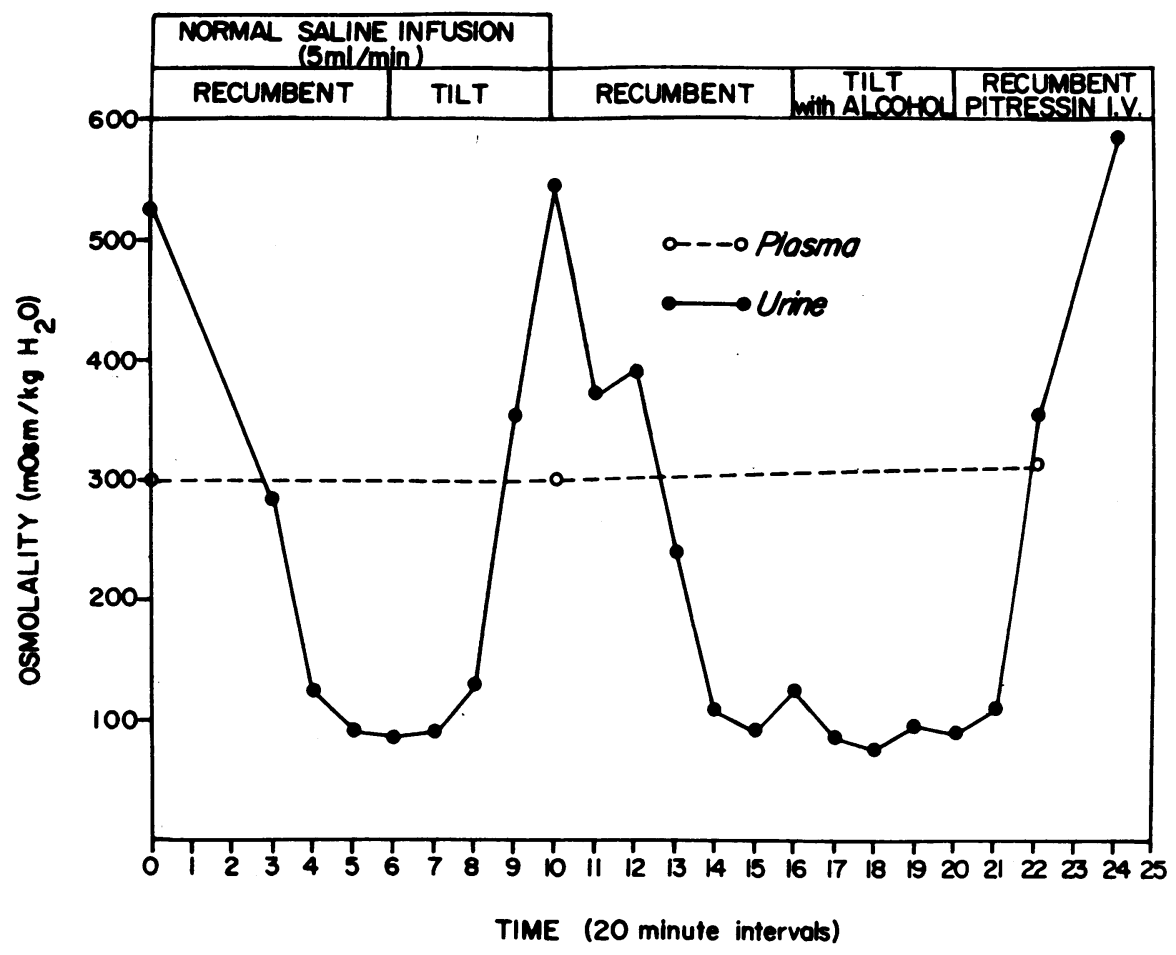

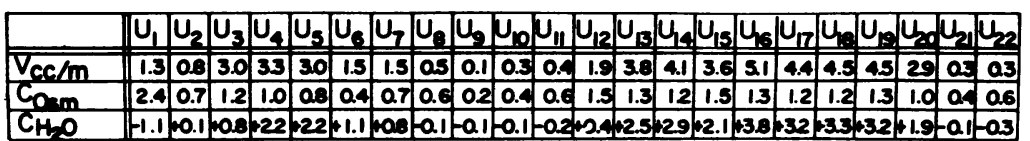

FIGURE 8 Interruption with orthostasis of a water diuresis induced by normal saline infusion. After overnight dehydration, a water diuresis was established during recumbency with normal saline infusion $(5 \mathrm{ml} / \mathrm{min})$. Tilting to $75^{\circ} \mathrm{C}$ for $90 \mathrm{~min}$ resulted in urinary concentration with urine osmolality rising from 87 to $543 \mathrm{mOsm} / \mathrm{kg}$ of water. Water diuresis resumed with recumbency. Tilting was repeated $15 \mathrm{~min}$ after administration of ethyl alcohol orally. Urinary concentration was not observed. During this study urine was collected at 20 -min intervals by an indwelling bladder catheter. Table, at bottom, depicts $\mathrm{V}, \mathrm{C}_{\mathrm{Osm}}$, and $\mathrm{C}_{\mathrm{H}_{2} \mathrm{O}}$ in milliliters per minute for individual determinations corresponding in sequence to points for urine osmolality.

servations of excretion of a dilute urine despite an elevated plasma osmolality (9-14), the failure of fluid loading to return the plasma osmolality to normal (914 ), and concentration of the urine when plasma osmolality was raised to high levels by fluid deprivation (1015) have been used to support this postulated resetting of the hypothalamic "osmostat." This and other hypotheses including a primary disturbance in sodium metabolism (14) were considered in the investigation of this patient who presented with a sustained elevation of her plasma osmolality.

The normal creatinine clearance, the absence of azotemia and oliguria, and the normal aldosterone excretion rate are all evidence against severe extracellular fluid volume depletion. The failure of forced fluid administration to lower the plasma osmolality eliminates inadequate fluid intake as the sole cause of the hypernatremia. Likewise, the urine osmolality of $1410 \mathrm{mOsm} / \mathrm{kg}$ of water after exogenous vasopressin, the ability to dilute the urine to an osmolality of $60 \mathrm{mOsm} / \mathrm{kg}$ of water, and the range of urinary sodium concentration (1-206 mEq/ liter) indicate intact renal tubule function. Overproduction of aldosterone did not appear to be involved in sustaining the hypernatremia since aldosterone excretion, serum potassium, and bicarbonate were normal. All of these observations in addition to the demonstrated ability to maintain sodium balance under all of the conditions of the study indicate that an abnormality in sodium metabolism was not the cause of the sustained and fluctuating hyperosmolality. The evidence, therefore, suggests that the hyperosmolar syndrome was related to an abnormality in water metabolism. 


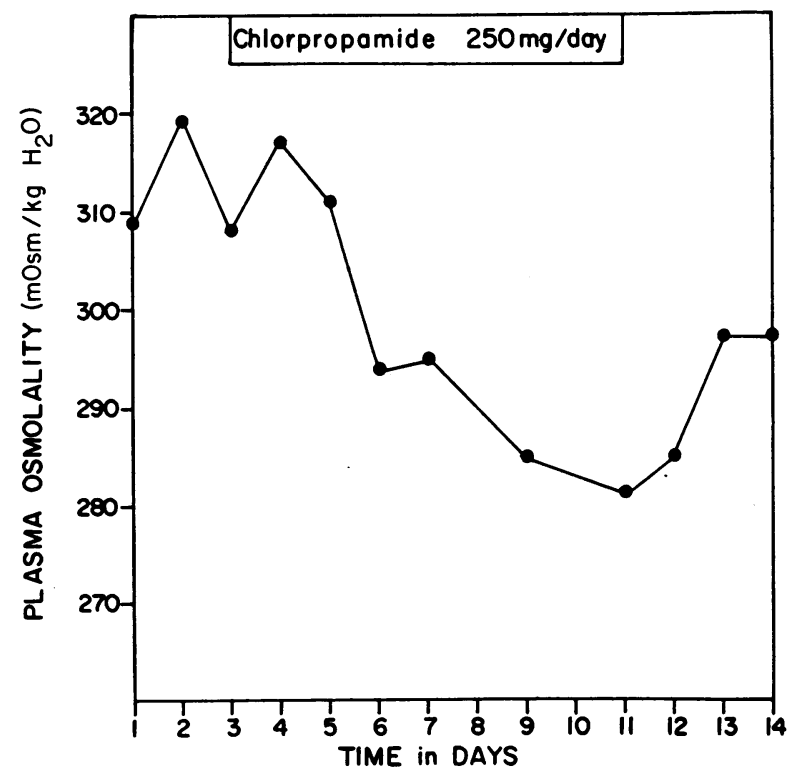

FIGURE 9 Response to chlorpropamide. A significant fall in plasma osmolality $\left(\mathrm{P}_{\mathrm{osm}}\right)$ was noted on the 4th day of therapy with $250 \mathrm{mg}$ of chlorpropamide daily. Response persisted for 2 days after cessation of the drug. Subsequent readministration of chlorpropamide resulted in a sustained lowering of $\mathrm{P}_{\mathrm{Osm}}$.

The patient was not totally deficient in antidiuretic hormone because concentration of the urine up to 710 mOsm occurred in the presence of a normal glomerular filtration rate and because urinary dilution followed alcohol ingestion (Fig. 2). The range of urine osmolalities from very dilute to very concentrated, rapid changes from dilute to concentrated or from concentrated to dilute urine noted in numerous experimental circumstances, and the response to alcohol all indicate that there was the ability to alter the secretion of antidiuretic hormone. Once the presence of antidiuretic hormone was established, the observation of urinary dilution at high plasma osmolality (Table III) suggested that regulation of hormone secretion was impaired. During the 23 days of observation on unrestricted fluid intake, the fluctuation of plasma osmolality between 298 and $323 \mathrm{mOsm} / \mathrm{kg}$ of water raised the possibility that the altered regulation of vasopressin secretion was not simply resetting of the "osmostat." If antidiuretic hormone secretion were regulated by osmotic stimuli at a higher plasma osmolality then the same narrow range of plasma osmolality known to occur at normal plasma osmolalities $(34,44)$ might be expected. In contrast, there was a marked fluctuation in the plasma osmolality of this patient (Fig. 1). Furthermore, as noted in the same figure, there was no correlation between plasma osmolality and either urinary concentration or fluid intake, both of which might be expected if osmotic stimuli were effective in regulating vasopressin secretion and fluid intake $(33,34)$.
The response to water deprivation (Table IV) further suggested that the resultant rise in urine osmolality was mediated by other than osmotic stimuli. A urine osmolality of $604 \mathrm{mOsm} / \mathrm{kg}$ of water was attained after $14 \mathrm{hr}$ of water restriction with an associated loss of $1.4 \mathrm{~kg}$ of body weight. In the early part of the study dilute urine was produced (Uosm $249 \mathrm{mOsm} / \mathrm{kg}$ of water) in spite of the fact that the initial plasma osmolality was elevated (Posm, $303 \mathrm{mOsm} / \mathrm{kg}$ of water). Earlier observations illustrating the patient's failure to secrete vasopressin at higher serum osmolalities than those recorded during this study would seem to indicate that resetting of the "osmostat" does not adequately explain this response to water deprivation and that volume was the predominant regulatory factor.

When hypertonic saline was infused (Fig. 5), the plasma osmolality increased from 289 to $339 \mathrm{mOsm} / \mathrm{kg}$ of water, the urine remained dilute, and free water clearance increased. An infusion of isotonic saline (Fig. 6) also resulted in an increase in plasma osmolality from 303 to $320 \mathrm{mOsm} / \mathrm{kg}$ of water and sustained water diuresis. In both instances a concentrated urine was excreted only when exogenous vasopressin was infused. Normal subjects would be expected to secrete vasopressin and concentrate their urine in response to a small rise in plasma osmolality (1-2\%) induced by hypertonic saline infusion $(34,45)$. The normal response to rapid infusions (25-65 $\mathrm{ml} / \mathrm{min})$ of large volumes (1.5-3.0 liters) of isotonic saline would be a transient water diuresis due to the effect of volume expansion to inhibit vasopressin secretion (46-48). A small rise (1-2\%) in the plasma osmolality caused by the water diuresis would be expected to be an effective stimulus for the resecretion of vasopressin and termination of this water diuresis $(46-48)$. The induction of a sustained water diuresis with much smaller amounts of isotonic saline $(5 \mathrm{ml} / \mathrm{min}$, total $400-500 \mathrm{ml}$ ) demonstrated the effect of volume expansion to inhibit vasopressin secretion. The failure of acute elevation of plasma osmolality to terminate the water diuresis with both types of saline solutions demonstrates the relative ineffectiveness of osmotic pressure to stimulate vasopressin secretion. These results suggested that in the presence of such impaired osmotic regulation of vasopressin secretion volume factors might predominate. This possibility was tested further by examining the patient's response to changes in effective circulating volume. The water diuresis induced by water ingestion with the patient in the recumbent position was interrupted by orthostasis (Fig. 7). The water diuresis resumed when the patient was returned to the recumbent posture (Fig. 7). The inhibition of the antidiuresis of orthostasis by alcohol ingestion indicates the response was related to the secretion of antidiuretic hormone (32, 38, 39). Furthermore, as noted in Fig. 8, a saline-induced wise resumed with recombency. Alcohol once again in- 
hibited the antidiuretic response to orthostasis. The plasma osmolality continued to rise $(300-316 \mathrm{mOsm} / \mathrm{kg}$ of water) and exogenous vasopressin was needed to terminate the water diuresis. The induction of a water diuresis with effective volume expansion, saline or recumbent position, and its termination with effective volume contraction (orthostasis) indicate that the vasopressin secretory mechanism could be regulated by volume stimuli. Once again osmotic stimuli were seen to be ineffective in producing an antidiuresis.

The hypothalamic location of this patient's neurologic lesion, almost certainly histiocytic infiltration as was found on the lung biopsy, would be quite consistent with disruption of osmoreception. Histiocytosis has previously been reported as a cause of essential hypernatremia $(11,16,17)$ but a variety of other hypothalamic lesions have also been associated with this syndrome. These include pineal germinoma (10), surgery for craniopharyngioma (12) and cerebral artery aneurysm (14), microcephaly (13), and glioma (17). Verney (34) initially introduced the concept of neural receptive elements monitoring plasma osmolality and effecting an appropriate release of $\mathrm{ADH}$ when osmolality rises. More recent studies have similarly indicated that a fall in plasma osmolality produced by intracarotid water infusion results in a water diuresis by central inhibition of vasopressin secretion (49). It has been suggested that the responsive cells might be activated by shrinking and swelling $(50,51)$. Jewell and Verney $(21)$ presented evidence eliminating many regions of the brain as sites of osmoreception and implicating the anterior hypothalamic area. They favored the region of the supraoptic nucleus as the primary site of osmoreception. Much additional evidence has since been accumulated to support their view (52), but other nearby regions may also be involved (53-55). There is also evidence to sugggest that there are blood volume receptors in areas such as the left atrium, carotid artery, and aortic arch which mediate ADH secretion by reflex mechanisms (56-61). Blood volume contraction stimulates $(57,62-64)$ and expansion inhibits $(61,64,65)$ ADH secretion. However, the stimulation or inhibition of $\mathrm{ADH}$ secretion appears to be governed by the net effect of osmotic and volume factors operative $(64,66-68)$. Under ordinary circumstances, such as hydropenia and overhydration, volume and osmotic factors are acting in a parallel fashion to either stimulate or inhibit vasopressin secretion. When these two stimuli act in opposite directions, such as in expansion with hypertonic saline (45) or in hypotonic contraction $(66,69-71)$, vasopressin seems to be secreted in response to a rising plasma osmolality and falling volume $(45,66,69-71)$. The former observation water diuresis was also inhibited by orthostasis and likeis the basis of the usefulness of hypertonic saline in the differential diagnosis of polyuric states. Similarly, it is the resultant small rise in plasma osmolality which is thought to limit the water diuresis which normally occurs in response to isotonic expansion in man (46-48). From these normal physiologic responses and the concept that ordinarily both osmotic and volume factors influence the secertion of vasopressin, it might be predicted that in the absence of effective osmotic regulation isotonic or hypertonic expansion, by inhibiting ADH secretion, would result in a sustained water diuresis. Such responses were indeed observed in the present patient (Figs. 5 and 6). With impaired osmotic mediation of $\mathrm{ADH}$ secretion, other stimuli which act to inhibit its secretion, such as alcohol ingestion or cold exposure, might also result in a water diuresis in spite of a rising Posm. This was documented in response to alcohol administration (Fig. 2). In such circumstances, volume contraction would eventually serve as an effective stimulus for resecretion of $\mathrm{ADH}$. However, considerable fluctuations of $\mathrm{Posm}_{\mathrm{s}}$ would result. It is of course possible that the patient's failure to terminate water diuresis during saline infusion despite rising plasma osmolality reflected an inability to release acutely sufficient vasopressin because of partial deficiency of this hormone. However, termination of a saline-induced water diuresis mediated by vasopressin secretion in response to orthostasis makes this possibility unlikely.

Elevated and fluctuating osmotic pressure would then be a consequence of $(a)$ loss of the sensitive osmotic regulation of $\mathrm{ADH}$ secretion which normally maintains plasma osmolality at a relatively constant value (34) and $(b)$ intact volume modulation of $\mathrm{ADH}$ secretion which would result in overall water balance but a less stable plasma osmolality.

Little consideration has been given to the role of volume regulation of vasopressin secretion in the previous reports of essential hypernatremia. In the present patient and in others reported (9-14), it was not possible to completely correct hyperosmolality with increased fluid administration. Rather, water diuresis was observed with plasma osmolality still elevated. Inhibition of vasopressin secretion by the volume expansion which accompanies such fluid loading could explain this observation. Further, several patients with essential hypernatremia were noted to concentrate their urine when plasma osmolality was raised to higher levels by fluid deprivations (11-15). Such urinary concentration is not necessarily related to an elevated osmotic threshold for vasopressin release. Volume contraction, a concomitant of fluid deprivation, may have been the important factor in vasopressin release in these instances. In only a few patients has hypertonic saline been employed as a means of evaluating the effectiveness of osmotic stimuli regulating vasopressin secretion. A decrease in urinary flow

Volume Regulation of Vasopressin Secretion

109 
and a small rise in urine osmolality was reported in each $(10,14,15)$, but in only one (10) did the urine osmolality rise above plasma in response to hypertonic saline. Such differences might be explained by the degree to which osmotic regulation of vasopressin secretion is impaired. However, a more systemic evaluation of the role of both osmotic and volume factors in the regulation of vasopressin secretion may serve to clarify further the pathophysiology of this complex disorder.

Finally, based on the formulations proposed, patients such as the present one may offer the rare opportunity to examine in man volume regulation of antidiuretic hormone secretion relatively independent of the usual influence of concomitant osmotic factors. Indeed, the present data would seem to lend further support to the concept of volume regulation of vasopressin secretion in man.

\section{ACKNOWLEDGMENTS}

We are indebted to Rebecca J. Clare for her expert technical assistance and to Sally A. Sawyer and Stephanie Koenig for their secretarial help. We are especially grateful to Miss Regina Onda and her dietary staff, Mrs. Bonita Levine, Miss Linda Pape, and the excellent nursing staff of the Clinical Research Unit. We would like to give special thanks to Dr. William M. Cooper for referring this most interesting patient to us for study.

This work was supported in part by Grants AM 1191102 , AM 10949, FR 56, and AM 05047 from the National Institutes of Health, U. S. Public Health Service.

\section{REFERENCES}

1. Zierler, K. L. 1958. Hyperosmolarity in adults: a critical review. J. Chronic Dis. $7: 1$.

2. Christie, S. B. M., and E. J. Ross. 1968. Ectopic pinealoma with adipsia and hypernatremia. Brit. Med.J. 2: 669.

3. Skultety, F. M., and R. J. Joynt. 1963. Clinical implications of adipsia. J. Neurosurg. 20: 793.

4. Hays, R. M., P. R. McHugh, and H. E. Williams. 1963. Absence of thirst associated with hydrocephalus. N. Engl. J. Med. 269: 227.

5. Travis, L. B., W. F. Dodge, J. D. Waggener, and C. Kashemsant. 1967. Defective thirst mechanism secondary to hypothalamic lesion: studies in a child with adipsia, polyphagia, obesity, and persistent hyperosmolarity. J. Pediat. 70: 915.

6. Crigler, J. R., and S. Suh. 1961. Hyperosmolarity following radical surgical treatment of craniopharyngioma. Amer. J. Dis. Child. 102: 81.

7. Truniger, B., and D. Kuenzler. 1962. Chronic hyperosmolarity and hypothalamic lesions. On the pathogenesis of occult hypersalemic diabetes insipidus. Klin. Wochenschr. 40: 872 .

8. Engstrom, W. W., and A. Liebman. 1953. Chronic hyperosmolarity of the body fluids with a cerebral lesion insipidus and anterior pituitary insufficiency. Amer. J. Med. 15 : 180.

9. Goldberg, M., G. Weinstein, J. Adesman, and S. J. Bleicher. 1967. Asymptomatic hypovolemic hypernatremia, a variant of essential hypernatremia. Amer. J. Mcd. 43: 804 .
10. Kastin, A. J., M. B. Lipsett, A. K. Ommaya, and J. M. Moser. 1965. Asymptomatic hypernatremia, physiological and clinical study. Amer. J. Med. 38: 306.

11. Avioli, L. V., L. E. Earley, and H. K. Kashima. 1962. Chronic and sustained hypernatremia, absence of thirst, diabetes insipidus, and adrenocorticotrophin insufficiency resulting from widespread destruction of the hypothalamus. Ann. Intern. Med. 56: 131.

12. Mahoney, J. H., and A. D. Goodman. 1968. Hypernatremia due to hypodypsia and elevated threshold for vasopressin release. N. Engl. J. Med. 279: 1191.

13. Segar, W. E. 1966. Chronic hyperosmolality. Amer. J. Dis. Child. 112: 318.

14. Pleasure, D., and M. Goldberg. 1966. Neurogenic hypernatremia. Arch. Neurol. 15: 78.

15. Golonka, J. E., and J. A. Richardson. 1970. Postconcussive hyperosmolality and deficient thirst. Amer. J. Med. 48: 261 .

16. Leaf, A., A. R. Mamby, H. Rasmussen, and J. P. Marasco. 1952. Some hormonal aspects of water excretion in man. J. Clin. Invest. 31: 914.

17. Wise, B. L. 1962. Neurogenic hyperosmolarity (hypernatremia). Neurology. 12: 453.

18. Weitzman, E. D., and M. H. Triedman. 1960. Hyperosmolarity associated with hypothalamic lesion. Neurology. 10: 584 .

19. Andersson, B., and S. M. McCann. 1955. The effect of hypothalamic lesions on the water intake of the dog. Acta Physiol. Scand. 35: 312.

20. Lederis, K. 1962. The distribution of vasopressin and oxytocin in hypothalamic nuclei. In Neurosecretion. $\mathrm{H}$. Heller and R. B. Clark, editors. Academic Press Inc., New York. 227.

21. Jewell, P. A., and E. B. Verney. 1957. An experimental attempt to determine the site of neurohypophysial osmoreceptors in the dog. Phil. Trans. Roy. Soc. London Ser. B Biol. Sci. 240: 197.

22. Andersson, B., and S. M. McCann. 1955. Drinking, antidiuresis and milk ejection from electrical stimulation within the hypothalamus of the goat. Acta Physiol. Scand. 35: 191.

23. Peters, J. P. 1950. Sodium, water and edema. J. Mt. Sinai Hosp. 17: 159.

24. Welt, L. G. 1962. Hypo- and hypernatremia. Ann. Intern. Med. 56: 161.

25. Davis, B. B., M. E. Bloom, J. B. Field, and D. H. Mintz. 1969. Hyponatremia in pituitary insufficiency. Metab. (Clin. Exp.). 18: 821.

26. Führ, J., J. Kaczmarczyk, and C.-D. Krüttgen. 1955. Eine einfache colorimetrische methode zur insulinbestimmung für nieren-clearance-untersuchungen bei stoffwechselgesunden und diabetikern. Klin. Wochenschr. 33: 729.

27. Bonsnes, F. W., and H. H. Taussky. 1945. On the colorimetric determination of creatinine by the Jaffe Reaction. J. Biol. Chem. 158: 581 .

28. Kliman, B., and R. E. Peterson. 1960. Double isotope derivative assay of aldosterone in biological extracts. J. Biol. Chem. 235 : 1639.

29. Vagnucci, A. H. 1969. Selective aldosterone deficiency. J. Clin. Endocrinol. Metab. 29: 279.

30. Pitts, R. F. 1963. Physiology of the kidney and body fluids. Year Book Medical Publishers, Inc., Chicago. 1st edition. 24.

31. Berliner, R. W., and D. G. Davidson. 1956. Production 
of hypertonic urine in the absence of pituitary antidiuretic hormone. J. Clin. Invest. 35: 690.

32. Strauss, M. B., J. D. Rosenbaum, and W. P. Nelson III. 1950. The effect of alcohol on the renal excretion of water and electrolyte. J. Clin. Invest. 29: 1053.

33. Wolf, A. V. 1950. Osmometric analysis of thirst in man and dog. Amer. J. Physiol. 161: 75.

34. Verney, E. B. 1947. The antidiuretic hormone and the factors which determine its release. Proc. Roy. Soc. Ser. B Biol. Sci. 135: 25.

35. Crawford, B., and $H$. Ludemann. 1951. The renal response to intravenous injection of sodium chloride solutions in man. J. Clin. Invest. 30: 1456.

36. Papper, S., L. Saxon, J. D. Rosenbaum, and H. W. Cohen. 1956. The effects of isotonic and hypertonic salt solutions on the renal excretion of sodium. J. Lab. Clin. Med. 47: 776 .

37. Epstein, F. H., A. V. N. Goodyer, F. D. Lawrason, and A. S. Relman. 1951. Studies of the antidiuresis of quite standing: the importance of changes in plasma volume and glomerular filtration rate. J. Clin. Invest. 30: 63 .

38. Kleeman, C. R., M. E. Rubini, E. Lamdin, and F. H. Epstein. 1955. Studies on alcohol diuresis. II. The evaluation of ethyl alcohol as an inhibitor of the neurohypophysis. J. Clin. Invest. 34: 448.

39. Pearce, M. L., and E. V. Newman. 1954. Some postural adjustments of salt and water excretion. J. Clin. Invest. 33: 1089.

40. Arduino, F., F. P. J. Ferraz, and J. Rodrigues. 1966. Antidiuretic action of chlorpropamide in idiopathic diabetes insipidus. J. Clin. Endocrinol. Metab. 26: 1325.

41. Meinders, A. E., J. L. Touber, and L. A. DeVries. 1967. Chlorpropamide treatment in diabetes insipidus. Lancct. 2: 544 .

42. Webster, B., and J. Bain. 1970. Antidiuretic effects and complications of chlorpropamide therapy in diabetes insipidus. J. Clin. Endocrinol. Metab. 30: 215.

43. Andreani, D., G. A. Cinotti, and G. Stirati. 1969. Chlorpropamide in idiopathic diabetes insipidus. Mctab. (Clin. Exp.). 18: 874.

44. Czaczkes, J. W., C. R. Kleeman, and M. Koenig. 1964. Physiologic studies of antidiuretic hormone by its direct measurement in human plasma. J. Clin. In''cst. 43: 1625.

45. Moses, A. M., and D. H. P. Streeten. 1967. Differentiation of polyuric states by measurement of responses to changes in plasma osmolality induced by hypertonic saline infusions. Amer. J. Med. 42: 368.

46. Welt, L. G., and J. Orloff. 1951. The effects of an increase in plasma volume on the metabolism and excretion of water and electrolytes by normal subjects. $J$. Clin. Invest. 30: 751 .

47. Strauss, M. B., R. K. Davis, J. D. Rosenbaum, and E. C. Rossmeisl. 1951. "Water diuresis" produced during recumbency by the intravenous infusion of isotonic saline solution. J. Clin. Invest. 30: 862.

48. Ladd, M. 1950. Effect of prehydration on the response to saline infusion in man. J. Appl. Physiol. 3: 379

49. Arndt, J. O. 1965. Diuresis induced by water infusion into the carotid loop of unanesthetized dogs. Pfleugers Arch. Gesamte Physiol. Menschen Tiere. 282: 301.

50. Jewell, P. A. 1953. Occurrence of vesiculated neurons in the hypothalamus of the dog. J. Physiol. (London). $121: 167$.

51. Alanis, J., and B. H. C. Matthews. 1952. The mechanoreceptor properties of central neurones. J. Physiol. (London). 117: 59 .
52. Joynt, R. J. 1966. Verney's concept of the osmoreceptor. A review and further experimental observations. Arch. Neurol. 14: 331 .

53. Dierickx, K. 1962. The dendrites of the preoptic neurosecretory nucleous of Rana Temporaria and the osmoreceptors. Arch. Int. Pharmacodyn. Ther. 140: 708.

54. Dingman, J. F., K. Benirschke, and G. W. Thorn. 1957. Studies of neurohypophyseal function in man. Amer. $J$. Med. 23: 226.

55. Holland, R. C., B. A. Cross, and C. H. Sawyer. 1959. EEG correlates of osmotic activation of the neurohypophyseal milk-ejection mechanism. Amer. J. Physiol. 196: 796

56. Henry, J. P., O. H. Gauer, and J. L. Reeves. 1956. Evidence of the atrial location of receptors influencing urine flow. Circ. Res. 4: 85.

57. Share, L., and M. N. Levy. 1962. Cardiovascular receptors and blood titer of antidiuretic hormone. Amer. J. Physiol. 203: 425.

58. Share, L. 1965. Effects of carotid occlusion and left atrial distention on plasma vasopressin titer. Amer. J. Physiol. 208: 219.

59. Shu'ayb, W. A., W. H. Moran, Jr., and B. Zimmerman. 1965. Studies of the mechanism of antidiuretic hormone secretion and the post-commissurotomy dilutional syndrome. Ann. Surg. 162: 690.

60. Gupta, P. D., J. P. Henry, R. Sinclair, and R. Von Baumgarten. 1966. Responses to atrial and aortic baroreceptors to nonhypotensive hemorrhage and to transfusion. Amer. J. Physiol. 211: 1429.

61. Johnson, J. A., W. W. Moore, and W. E. Segar. 1969. Small changes in left atrial pressure and plasma antidiuretic hormone titers in dogs. Amer. J. Physiol. 217: 210

62. Weinstein, H., R. M. Berne, and H. Sachs. 1960. Vasopressin in blood; effect of hemorrhage. Endocrinology. $66: 712$.

63. Henry, J. P., P. D. Gupta, J. P. Meehan, R. Sinclair and L. Share. 1968. The role of afferents from the low pressure system in the release of antidiuretic hormone during non-hypotensive hemorrhage. Can. J. Physiol. Pharmacol. 46: 287.

64. Smith, H. W. 1957. Salt and water volume receptors. Amer. J. Med. 23: 623.

65. Baratz, R. A., and R. C. Ingraham. 1960. Renal hemodynamics and antidiuretic hormone release associated with volume regulation. Amer. J. Physiol. 198: 565.

66. Arndt, J. O. 1965. Diuresis induced by water infusion into the carotid loop and its inhibition by small hemorrhage. The competition of volume- and osmocontrol. Pflengers Arch. Gesamte. Physiol. Menschen Tiere. 282: 313.

67. Johnson, J. A., J. E. Zehr, and W. W. Moore. 1970. Effect of separate and concurrent osmotic and volume stimuli on plasma ADH in sheep. Amer. J. Physiol. 218: 1273.

68. Gauer, H. O. 1968. Osmocontrol versus volume control. Fcd. Proc. $27: 1132$.

69. McCance, R. A. 1936. Experimental sodium chloride deficiency in man. Proc. Roy. Soc. Ser. B Biol. Sci. 119: 245.

70. Leaf, A., and A. R. Mamby. 1952. An antidiuretic mechanism not regulated by extracellular fluid tonicity. J. Clin. Invest. 31: 60 .

71. Young, T. K., and R. A. Phillips. 1967. Antidiuretic hormone release in the monkey during hypo- and hyper-osmotic dehydration. Proc. Soc. Exp. Biol. Med. 125: 1174.

Volume Regulation of Vasopressin Secretion 